\title{
palgrave
}

Multinational Corporations: Control Systems and Delegation Issues

Author(s): B. R. Baliga and Alfred M. Jaeger

Reviewed work(s):

Source: Journal of International Business Studies, Vol. 15, No. 2, Special Issue on Strategic

Planning, Autonomy and Control Processes in Multinational Corporations (Autumn, 1984), pp.

25-40

Published by: Palgrave Macmillan Journals

Stable URL: http://www.jstor.org/stable/154230

Accessed: $16 / 08 / 2012$ 04:35

Your use of the JSTOR archive indicates your acceptance of the Terms \& Conditions of Use, available at

http://www.jstor.org/page/info/about/policies/terms.jsp

JSTOR is a not-for-profit service that helps scholars, researchers, and students discover, use, and build upon a wide range of content in a trusted digital archive. We use information technology and tools to increase productivity and facilitate new forms of scholarship. For more information about JSTOR, please contact support@jstor.org. 


\title{
MULTINATIONAL CORPORATIONS: CONTROL SYSTEMS AND DELEGATION ISSUES
}

\author{
B. R. BALIGA* \\ Texas Tech University \\ ALFRED M. JAEGER * \\ McGill University (Canada)
}

\begin{abstract}
The paper has 2 major objectives: first, to identify control and delegation issues confronting multinational corporation managers; second, to develop a conceptual model to assist multinational corporation managers in selecting appropriate control systems and determining the extent of delegation to be provided to subsidiary managers. Finally, the paper suggests directions for future research.
\end{abstract}

Students of organizations have been greatly concerned with issues of control and decision making [Mintzberg 1979; Child and Keiser 1978; Khandwalla 1977; Child 1977, 1972; Edström and Galbraith 1977; Beyer and Lodahl 1976; Donaldson 1975; Ouchi and McGuire 1975; Kochen and Deutsch 1973; Galbraith 1973; Hall 1972, 1968; Allison 1971; Perrow 1970; Hage and Aiken 1967; Emery 1969; Crozier 1964; Braybrooke and Lindblom 1963; Simon 1957]. As organizations grow in size they tend to differentiate, that is, the various components of the organization differ on the dimensions of time horizons, goals, interpersonal orientation, and the formality of their structures [Lawrence and Lorsch 1967]. The coordination and integration of the different units emerge as very specific problems that top management has to grapple with [Robbins 1983; Mintzberg 1979; Child 1977; Lorsch 1970]. These problems are all the more acute in the case of multinational corporations (MNCs) that are geographically dispersed and that operate in environments of varying degrees of complexity, heterogeneity, stability, and hostility [Fayerweather 1978]. Various coordinating mechanisms, including direct supervision, mutual adjustment, and standardization of input skills, work processes, and outputs [Mintzberg 1979], are utilized along with control and decision-making systems to integrate the various units. An understanding of these is, therefore, of crucial importance to all managers, particularly the multinational corporation managers for whom these problems are more acute.

This paper will first examine the concept of control and decision making in the context of multinational corporations. Subsequent sections will consider some specific contingencies that affect control and decision making. Finally, a model will be developed to assist multinational corporation managers in selecting systems of control and decision making.

According to Child [1973, p. 117], "Control is essentially concerned with regulating the activities within an organization so that they are in accord with the expectations established in policies, plans, and targets." This definition is

\footnotetext{
${ }^{*} \mathrm{~B}$. R. Baliga is Assistant Professor of International Business and Business Policy in the College of Business Administration, Texas Tech University. He is the co-author of two books on Multinational Corporation Strategy and several articles in strategic management.

${ }^{\star *}$ Alfred M. Jaeger is Associate Professor of Organizational Behavior and Management Policy at the Faculty of Management, McGill University. He has written several articles in the areas of multinational management, organizational control, and strategic management and has consulted in these fields.

The authors wish to thank the Graduate School and the College of Business Administration of Texas Tech University as well as the Research Committee of the Faculty of Management, McGill University, for their direct support of this research.

The article benefited considerably from 3 anonymous reviewers.
} 
consistent with Tannenbaum's definition [1968] which states that the importance of control is to ensure "achievement of the ultimate purposes of the organization." Control, therefore, encompasses any process in which a person (or group of persons, or organization of persons) determines or intentionally affects what another person, group, or organization will do.

At the heart of control is the monitoring process. Ouchi [1977] points out that there are only 2 phenomena which can be monitored and evaluated: behavior and output. If output measures are readily available and valid, then output is monitored and controlled. Mintzberg [1979] labels this "performance control." The focus here is on ends, leaving organizational members flexibility in choosing the means. If output measures are not readily available or their validity is questionable, then another type of control, which Mintzberg labels "action planning," can be employed. Action planning is considerably more restrictive than performance control. It imposes specific decisions and actions at specific points in time. If action planning is carried through to its logical extreme, behavior formalization results wherein the means by which actions and decisions to be carried out are specified. In instances where it is difficult, if not impossible, to specify, monitor, and control behavior or output (foreign missionaries, for example), organizations may have no choice but to indoctrinate their members to the organizational values and mission and hope that their members' acts are consistent with organizational intent. The consequences of member actions in these organizations may not be known for fairly long periods of time, making dayto-day control difficult.

Child [1973, 1972] asserts that organizations can choose between personal control systems or bureaucratic control systems in order to monitor output or behavior. In the MNC context, the personal or direct type of control involves placing a number of trustworthy personnel from headquarters in key positions in the subsidiary to supervise subsidiary functioning. The bureaucratic mode, on the other hand, utilizes extensive sets of rules, regulations, and procedures that clearly limit subsidiary management's role and authority. Edström and Galbraith [1977] claim that a third type of control exists: control by socialization. This is characterized by a significant proportion of expatriates in upper and middle management positions, frequent information exchange between headquarters and subsidiaries, and a de-emphasis of formalization.

It is the contention of this paper that the "personal" type of control and "control by socialization" are specific attributes of what can be termed "cultural control." The focus, therefore, will be on cultural control and bureaucratic control as the 2 dominant control systems that corporate management can utilize to control their subsidiaries. These can be conceptualized as Weberian "ideal types" and in their extreme "pure" form can be regarded as opposite approaches to organizational control. Although such ideal types are never found in the pure form in reality, they are a useful tool for the conceptualization of organizational processes.

Bureaucratic Control
The bureaucratic model is extensively employed in Western organizations. Child [1973] notes that it consists of the utilization of a limited and explicit set of codified rules and regulations which delineate desired performance in terms of output and/or behavior. For an individual to become a functional member of a bureaucratic organization, he must accept the legitimacy of the organization's authority, and he must learn the rules and regulations so that he can indeed follow them. Etzioni [1980] points out that the authority and power exercised in this system is through control over resources, that is, it is of the "remunerative" type, and personal involvement is "calculative" or relatively limited. In Schein's [1980] terms, the individual must only accept the pivotal organizational norms, and these are fairly narrow in scope.

A bureaucratic control system has several implications for the selection, training, 
and monitoring of organizational members. Persons must be found who have the technical skills required (or are trainable), who will accept the organization's authority, and who can learn the organization's rules and regulations and perform in accordance with them. The selection process is fairly straightforward, as the "zone of indifference" [Barnard 1951] required of individuals is relatively narrow. Training is also relatively straightforward: new members must be taught the rules and regulations which are explicit and written down. In addition, they must learn whatever technical competence is required of their position. Monitoring in a bureaucratic system involves comparing an individual's behavior and output to the standards set forth in the rules and regulations and applying the rewards or sanctions prescribed therein.

A notable alternative to the bureaucratic model is one that is prevalent in the larger Japanese organizations as well as some Western organizations [Deal and Kennedy 1982]. The Japanese organization has been described in some detail by a number of researchers [for example, Hatvany and Pucik 1981; Pascale and Athos 1981; Clark 1979; Johnson and Ouchi 1974; Rohlen 1974; and Abegglen 1958]. Most noticeable among the Western organizations with an organizational culture are Type Z organizations [Ouchi 1981], and a number of the "excellent" firms described by Peters and Waterman [1983]. Control in all of these organizations is more implicit and informal rather than explicit and formal. The direction that is provided to organizational members is of an aggregate rather than specific nature. Employees are employed for a long period or even for life; they are very loyal to the organization and they behave in accordance with the company "way." Even though explicit formal control mechanisms are present, control is essentially based on a broad organization-wide culture.

Organizational culture has been defined as a "pattern of beliefs and expectations shared by the organization's members" [Schwartz and Davis 1981, p. 32]. It generates over time a system of symbols, language, ideology, rituals, images, and myths that shapes the behavior of individuals and groups in the organization. Keesing [1974] views culture as an individual's "theory of what his fellows know, believe and mean, his theory of the code being followed, the game being played." In a cultural control organization, there exists such an inferred organizational code, an organizational game, which is an important guide to behavior in addition to whatever explicit rules do exist. This view of corporate culture of an adaptive and regulatory mechanism has also been identified in recent reviews of the organization theory literature [Smircich 1983].

A number of organizational practices facilitate the existence of a cultural control system. Most important are long-term employment guarantees, consensual decision making, and nonspecialized career paths. Linton [1936], the anthropologist, has pointed out that stability of membership in a cultural group is necessary for the existence and continuity of a culture. Long-term employment provides such stability. The prospect that a new employee will remain for a long period of time allows the organization to make an investment in the socialization of the individual. [See Hatvany and Pucik 1981 for a further description of this process in large Japanese firms.] The consensual decision-making process forces interaction around organizational issues among organizational members. This interaction is one of the ways in which, through a process of repeated interactions over time, cultural values become systematized and shared. In addition, the fact that career paths in a cultural control organization are less than totally specialized means that persons are rotated through the various functional areas of the organization, thus contributing to a greater organization-wide culture. A less than total commitment to a functional specialty on the part of organizational members reduces competition from outside professional groups for members' loyalty, thus enhancing the potential strength of the corporate culture. As a result, an employee develops the 
"moral commitment" to the organization which Etzioni [1980] associates with the normative type of power and authority.

The use of a cultural control system has several implications for the selection, training, and monitoring of organizational members. Members of an organization with cultural control must be integrated into the organizational culture in order to be functional members of the organization. Therefore, selection of members is of prime importance. In addition to having the requisite skill necessary for the job, a candidate for organizational membership must be sympathetic to the organizational culture and must be willing to learn and to accept its norms, values, and behavioral prescriptions. Thus, the initial "zone of indifference" required of new members is fairly broad and specific.

Compared to a bureaucratic control system, training and socialization in a cultural control organization are also more important. An organizational member must not only learn a set of explicit, codified rules and regulations, but he must also learn and become a part of a subtle and complex control system which consists of a broad range of "pivotal" values. Thus, training and socialization can be quite intense and extensive. The degree of socialization required is reduced if the broader societal culture is approximately similar to that of the organization.

Monitoring in a pure cultural control system occurs through interpersonal interactions. All members of the culture are familiar with and share its expectations. Performance and compliance with the culture are observed during the course of interpersonal interactions. Feedback is given on a person-to-person basis and can be of a subtle nature. In addition, a culture is a very rich and broad guide to behavior, so that an individual and the persons around him will always have an implicit sense of his performance in the context of that culture. The contrast between bureaucratic control and cultural control is summarized in Figure 1.

The notion of the use of an organizational culture for control of MNC subsidiaries and the processes associated with such control have been examined by Edström and Galbraith [1977]. They studied the transfer of managers between countries in 3 European multinational firms. They concluded that the transfer of managers from subsidiary to subsidiary was a distinct control strategy in one firm. This process created international, interpersonal verbal information networks throughout the firm which were utilized for coordination and control. On a more global level, Stopford and Wells [1972] point out that one way of combatting control problems is the creation of a sense of cooperation and shared values among organization members around the world. They also point out that this requires

FIGURE 1

Comparison of Bureaucratic and Cultural Control Mechanisms

\begin{tabular}{|c|c|c|}
\cline { 2 - 3 } \multicolumn{1}{c|}{} & \multicolumn{2}{c|}{ TYPE OF CONTROL } \\
\hline $\begin{array}{l}\text { OBJECT } \\
\text { OF } \\
\text { CONTROL }\end{array}$ & $\begin{array}{c}\text { Pure } \\
\text { bureaucratic/ } \\
\text { formalized control }\end{array}$ & $\begin{array}{c}\text { Pure } \\
\text { cultural } \\
\text { control }\end{array}$ \\
\hline Output & $\begin{array}{c}\text { Formal } \\
\text { performance } \\
\text { reports }\end{array}$ & $\begin{array}{c}\text { Shared norms } \\
\text { of } \\
\text { performance }\end{array}$ \\
\hline Behavior & $\begin{array}{c}\text { Company } \\
\text { manuals }\end{array}$ & $\begin{array}{c}\text { Shared } \\
\text { philosophy } \\
\text { of } \\
\text { management }\end{array}$ \\
\hline
\end{tabular}


heavy expenditures for communication, including frequent meetings and retraining sessions.

A final example of studies of organizational culture in a multinational firm is the retrospective look by Peter Kuin [1972] at his experiences as an executive with Unilever. He found that the "magic" which helped Unilever to function multinationally was its distinct corporate culture. This culture was maintainable because of the long tenure of the employees and the fact that almost everyone knew English. He noted a distinct enculturation process which included in-house training programs and the rotation of managers around the world.

A parallel issue to that of control is delegation. Although most managers will readily agree that there are very valid reasons for delegation, such as, information overload at the top, need for responsiveness to local conditions, and stimulus for motivation down the hierarchy, they are often perplexed by the issue of "how much to delegate?" The issue is particularly complex in the context of multinational corporations. Geographic dispersal, in theory, should encourage headquarters to delegate as much as possible to subsidiary managers because this increases responsiveness to local conditions, results in decisions being made at the level where information is available, and assists in the development of subsidiary managers. Geographic dispersal, however, also raises fears among top management that subsidiary managers would work toward parochial ends and that headquarters managers' realization of this would come too late to prevent crises from developing. These fears tend to limit the actual delegation to subsidiary management.

Until recently, bureaucratic control, or bureaucratization, was equated with centralization; that is, the authority of lower level managers in the organization to make significant decisions was considered very limited or, in extreme cases, nonexistent. As a result, "bureaucracy" became a pejorative term. Based on data obtained from a study on the structuring of organizations, Child and Mansfield [1972] claimed that it was possible to have decentralization within a bureaucratic framework enabling people lower down in the organization to have power. Crozier [1964], however, has argued otherwise.

A review of other studies by Mintzberg [1979] did not discern any significant relationship between centralization and bureaucratization. He concluded that this finding was not surprising given the lack of conceptual clarity of the variables in these studies. Mintzberg proceeded to explain the conflicting nature of the finding on bureaucratization and centralization by claiming that previous research [Manns 1976; Mansfield 1973; Child 1972; Blau and Schoenherr 1971; Inkson, Pugh, and Hickson 1979; Pugh et al. 1963-64] had failed to discern between 2 types of bureaucracies - machine and professional. Machine bureaucracies operate in relatively simple and stable environments. They are characterized by the existence of a large number of relatively unskilled tasks and decisions that can be programmed easily [Simon 1957] by a cadre of analysts. Coordination is essentially achieved through standardization of work processes and outputs. Professional bureaucracies, on the other hand, operate in relatively complex but stable environments. They are staffed by "professionals" who are highly trained. Coordination is achieved essentially through standardization of skills, and members have relatively wide latitude in decision making; in other words, the organization is relatively decentralized.

Just as bureaucratization was equated with centralization, cultural control systems appear to have been equated with delegation or decentralization. In actuality, the absence of formalization may conceal a high level of centralization that is internally derived (through an extended process of socialization and indoctrination) rather than externally imposed through rules and regulations. In extreme cases, cultural control systems may lead to inappropriate decisions and 
actions based on trying to be consistent with the corporate culture rather than reacting appropriately to local conditions.

It is important to see that the choice of control systems and extent of delegation provided to subsidiary management can, in fact, be treated independently. There exist certain contingency factors, however, that may tend to reduce this independence. These factors will be considered in the following section.

CONTINGENCY FACTORS IN BUREAUCRATIC CONTROL, CULTURAL CONTROL, AND CENTRALIZATION

The age of the organization, its size (measured in terms of number of employees, asset base, and so on), and the age of the industry in which the organization functions have been found to have a significant influence on the degree of bureaucratization and centralization: the older the organization, the larger its size, and the older the industry in which it operates, the more bureaucratic and centralized the organization tends to be [Khandwalla 1977; Stinchcombe 1959; Kimberly 1976; Blau et al. 1976; Reimann 1973; Pugh et al. 1968]. On the other hand, organizational life-cycle studies indicate that organizations that are young and entrepreneurial tend to be nonbureaucratic [for example, Filley, House, and Kerr 1976; Litterer 1965].

Studies in the relationship between the environment and the organization point to the notion of the appropriate fit between the environment and the organization structure [Khandwalla 1977; Ansoff 1974; Duncan 1972; Galbraith 1973; Thompson 1967; Lawrence and Lorsch 1967; Burns and Stalker 1966]. The environments in these studies have been differentiated along the dimensions of stability, complexity, diversity, and hostility. The general notion appears to be that the more dynamic, complex, diverse, and hostile the environment is, then the more uncertainty it creates for organizational members. Studies suggest that such uncertainty is best coped with in an organization that is characterized by low levels of formalization and centralization [Lawrence and Lorsch 1967; Burns and Stalker 1966].

Multinational corporations are affected by the forementioned factors to varying degrees and in different directions. Many corporations become multinational only after a fairly long period of exclusive domestic activity [Dyas and Thanheiser 1976; Vernon 1966]. As a result, age pushes the multinational corporation toward increased levels of bureaucratization and centralization. One would expect that the multitude of environments and uncertainties which a MNC faces would restrain this growth of bureaucratization and centralization. As Greenwood and Hinings [1976] have observed, however, once organizations start routinizing, bureaucratizing, and centralizing some activities, they extend this tendency to all activities, however inappropriate this may be. This could explain why a number of multinational corporations bureaucratize and centralize their interactions with all their subsidiaries, ranging from those that operate in relatively certain environments to those that operate in very uncertain ones. Extreme cases of such bureaucratization and centralization give rise to the phenomenon of the "headless" subsidiary [Mintzberg 1979], subsidiaries that have essentially no significant decision-making authority.

The quest for power by headquarters' management may also be another critical factor affecting the tendency to bureaucratize and centralize operations in multinational corporate operations. Keeping tabs informally on operations becomes a difficult task in geographically dispersed multinational corporations. Hence, headquarters has to resort to formal methods to keep tabs and exercise power-in other words, bureaucratization and centralization.

Crises confronting subsidiaries appear to be another factor that increases the drift toward bureaucratization and centralization. The general response of many multinational corporation headquarters to poor performance on the part of the subsidiaries is to bureaucratize and centralize. Unfortunately, such bureaucratic centralization assumes that all contingencies are known and that these can be 
handled through rules and regulations. Although knowledge of a large proportion of the contingencies confronting a small organization operating in a simple and stable environment may, in fact, be known, this is highly unlikely to be the case in most multinational corporations. Furthermore, studies by Aguilar [1967], Jay [1970], and Scharpf [1977] show that such bureaucratization and centralization significantly reduce the quality and timeliness of information required to make critical decisions.

Turning to the factors which contribute to an increased use of cultural control systems in organizations, one notes that research in this area is very sketchy and basically anecdotal [Peters and Waterman 1983; Ouchi 1981; Pascale and Athos 1981; Jaeger 1983]. One conclusion which does emerge from the Japanese experience is that cultural homogeneity and exposure to a cultural ethos are quite important. If the societal culture values selflessness and orientation to the whole rather than independent parts, it is relatively easy for the organization to build, and reinforce, an orientation toward organizational rather than parochial goals. In an American environment, it has been suggested that a cultural control system could be appropriate in those cases where traditional societal sources of affiliation have disappeared, leaving individuals to seek affiliation and identity in the work organization [Ouchi and Jaeger 1978]. Cultural control systems, with their relatively high levels of delegation, appear also to have been fairly successful in jobs that require secrecy (for example, the C.I.A.) or in organizations with geographically remote organizational subunits, such as, those encountered in the U.S. Forest Rangers [Kaufman 1960].

Cultural control systems can only be sustained in those organizations where turnover is relatively low. Low turnover assists in the creation of organizational myths and stories which can be of immense value in indoctrinating new organizational members [Peters and Waterman 1982; Wilkins 1980]. Low turnover also facilitates a continuing process of reinforcing the organizational culture, and breeds trust which may, in turn, lead to increasing levels of delegation. Headquarters is likely to feel more comfortable with a well-trusted, indoctrinated subsidiary manager and to delegate more decisions to him than to someone else. High mobility and turnover, on the other hand, lead to the design of a system wherein the key concern is "how easily can we slot the next person in?" A well-designed set of rules and regulations obviously makes this easier, increasing the tendency to bureaucratize the system which, as noted previously, could increase the tendency to centralize.

Because, as pointed out earlier, large size tends to increase pressures toward adoption of a bureaucratic control system, an apparent prerequisite to using a cultural control system is to have subsidiaries that, within constraints set by technology, are relatively small. Ironically, in many instances, the very prospect of creating and maintaining a cultural control system can drive the organization toward a bureaucratic control system because the explicit costs (such as, greater use of expatriates, and frequent visits between headquarters and subsidiaries) associated with the headquarters-subsidiary relationship in a cultural control system tend to be greater than those of a bureaucratic control system [Wilkins and Ouchi 1983; Jaeger 1982; Kobayashi 1982; Hulburt and Brandt 1976]. Pressures for efficiency, therefore, could push all multinational corporations toward adopting bureaucratic control systems.

The role played by a particular subsidiary in the overall functioning of the multinational corporation generally has a significant influence on the extent of delegation provided to subsidiary management. For instance, top management of a subsidiary that essentially services a very circumscribed host market could probably be accorded a high level of delegation. Furthermore, if the subsidiary contribution to the objectives (sales, profitability, and so on) of the multinational corporation is very limited, then delegation to subsidiary management could be further increased. On the other hand, if a subsidiary is very critical to the overall 
functioning of the multinational corporation (as a provider of key inputs, absorber of outputs, key contributor to overall corporate objectives, and so on), then delegation would probably be considerably lower. In essence, the extent of delegation, or in Weick's [1976] terms the tightness or looseness of the coupling between headquarters and its subsidiaries, would vary as a function of the interdependence between the headquarters and its subsidiaries.

The degree of interdependence between headquarters and subsidiary would be affected principally by the type of strategy chosen [see Doz 1980] as well as the

\section{FIGURE 2}

Types of Interdependence within Organizations*

Corporate Headquarters

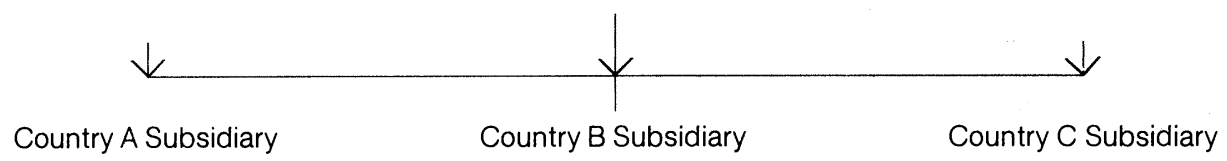

POOLED INTERDEPENDENCE

Corporate headquarters

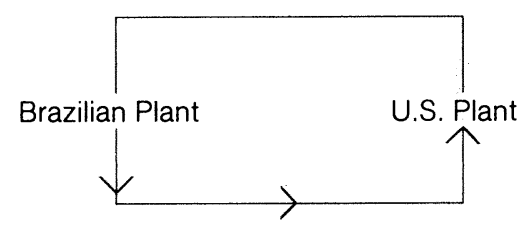

SEQUENTIAL INTERDEPENDENCE

Corporate headquarters

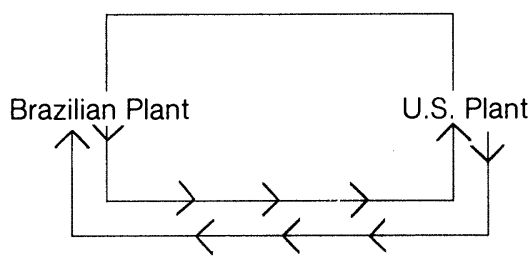

RECIPROCAL INTERDEPENDENCE

Key: $\longrightarrow \quad>\quad$ indicates direction of flow of materials.

* Based on Thompson [1967].

32 Journal of International Business Studies, Fall 1984 
nature of the firm's technology. Thompson [1967] identifies 3 types of interdependence that exist within organizations: pooled, sequential, and reciprocal. These are represented in Figure 2.

Pooled interdependence exists where organizational members share common resources but are otherwise quite autonomous.

Sequential interdependence exists where the output of one part of the system is fed into another part of the system. For example, if the General Motors (GM) subsidiary in Brazil supplies critical components (such as, engines) to GM, U.S., then these 2 units would be sequentially interdependent. Problems with supply from GM Brazil would have a ripple effect on GM's operations elsewhere, generating a greater need for control and ensuring that decisions taken by GM Brazil are consistent with those in other parts of the system.

Reciprocal interdependence is the most complex form of interdependence. Organizations or organizational units that are reciprocally interdependent feed their work back and forth among themselves. In terms of the above example, GM Brazil and GM U.S. would have a reciprocally interdependent relationship if GM U.S. worked on components provided by GM Brazil and shipped them back to GM Brazil for additional processing. Reciprocal interdependence generates the maximum need for control, coordination, and consistency in decision making. This need clearly would be greater if optimal functioning of the reciprocally interdependent parts of the organization were vital to the achievement of overall organizational goals and objectives. All these factors would move in a direction to strengthen the coupling, that is, reduce delegation to subsidiary management, since inappropriate decisions by subsidiary management can prove particularly costly to the MNC system.

Sequential and reciprocal interdependencies would probably call for some level of action planning. If the interdependencies are very significant, behavior formalization may be required because global output control measures would not be able to handle the interdependencies unless the interdependent systems were decoupled through building up of buffer inventories. Such buffering approaches generally tend to be fairly expensive and, in extreme cases, may produce results in conflict with the very reasons (global rationalization, for example) that generated the interdependencies in the first place.

In effectively managing its global operations, a multinational corporation has a degree of choice in the type of control relationship it has with each individual overseas subsidiary. Because no organization in the real world is actually a pure "ideal type," all organizations employ a mixture of both cultural and bureaucratic control mechanisms. (Those organizations that are classified as having cultural control have a more pervasive organizational culture and rely more heavily on this culture for control than do their bureaucratic control counterparts.) As an overseas subsidiary is usually quite distant from the headquarters, the interactions between organizational units occur via a relatively limited and definable set of channels. Furthermore, an overseas subsidiary is usually created by the headquarters, giving the headquarters great influence on how it will ultimately be managed. Thus, particularly in the case of the headquarters-subsidiary relationship, the headquarters of a multinational firm can exercise a choice in the control system employed and the extent of delegation.

This paper contends that management's choice of control systems and level of delegation should be based on their assessment of the interdependencies (pooled, sequential, reciprocal) generated by their strategies, the environmental uncertainties, and "cultural proximity." "Cultural proximity" is defined as the extent to which the host cultural ethos permits adoption of the home organizational culture. Those that permit easy adoption of the "home" (headquarters) culture would be considered high in cultural proximity. For instance, it would 
probably be easier for U.S. multinational corporations to transmit an organizational culture to a subsidiary in Australia than to one, say, in Indonesia. Physical proximity is also of value in terms of facilitating cultural proximity (for example, favoring Mexico over Chile). In addition, availability of communications (such as, telephone, telex, and air link) for frequent contact between home and host can also contribute to cultural proximity (for example, favoring Hong Kong over Shanghai). Cultural proximity becomes an extremely important variable in the selection of control systems, since socialization and indoctrination costs tend to be high.

From an overall perspective, dealing with interdependencies is most crucial. Environmentaluncertainty should be then considered and finally cultural proximity. Figure 3 presents the type of control systems and level of delegation that should be provided to subsidiary management under various conditions of interdependence, environmental uncertainty, and cultural proximity.

It should be noted that in 8 of 12 possible situations cultural control is recommended, and in only 3 situations are high levels of delegation recommended. The latter is in recognition of the fact that certain interdependencies require a level of centralization irrespective of the type of control system employed. The systems and levels of delegation described are "ideal"; a degree of variation is expected from these in reality. Nevertheless, the basic thrust should remain as close to the ideal as feasible.

Reciprocal interdependencies are best dealt with through the mechanism of mutual adjustment because the contingencies that can arise are too numerous to plan and formalize for effectively. In this case the cultural control system is the preferred mode, because bureaucratic control systems may generate so many exceptions that headquarters is constantly involved in the fire fighting mode. This implies that even when cultural proximity is low the multinational corporation may have to spend the necessary resources on socialization and indoctrination. The degree of centralization should be higher in those instances where environmental uncertainty is low and ought to be higher as well where cultural proximity is low. What all of this implies is that the costs associated with coping up with reciprocal interdependence may be far greater than the benefits.

Strategies that call for reciprocal interdependence, therefore, should be avoided by multinational corporations except where unavoidable or unless cultural proximity is high.

Many multinationals are confronted with either pooled or sequential interdependence. Under conditions of pooled interdependence, headquarters has the maximum number of degrees of freedom. Sequential interdependence requires more coordination (that is, centralization) between headquarters and subsidiary and is more likely to occur when multinational corporations follow strategies of global rationalization either voluntarily or as a result of demands made by host governments to export a percentage of outputs as a necessary condition for permission to invest.

Regardless of the type of interdependence, under conditions of high environmental uncertainty some degree of delegation should be provided to subsidiary management so that they may be more responsive to their local environment. Conversely, centralization could be extensive under conditions of low uncertainty. Under conditions of low cultural proximity, employment of cultural control systems would probably not be worth the expenditure. Where cultural proximity is high, socialization and indoctrination can be carried out more effectively, and use of cultural control would permit a higher level of delegation.

To the extent that the use of control system and level of delegation are appropriate to the interdependency, environmental uncertainty, and cultural proximity of the given situation, there should be no inherent problems in the headquarters-subsidiary relationship. If a mismatch exists, however, major problems could arise. 


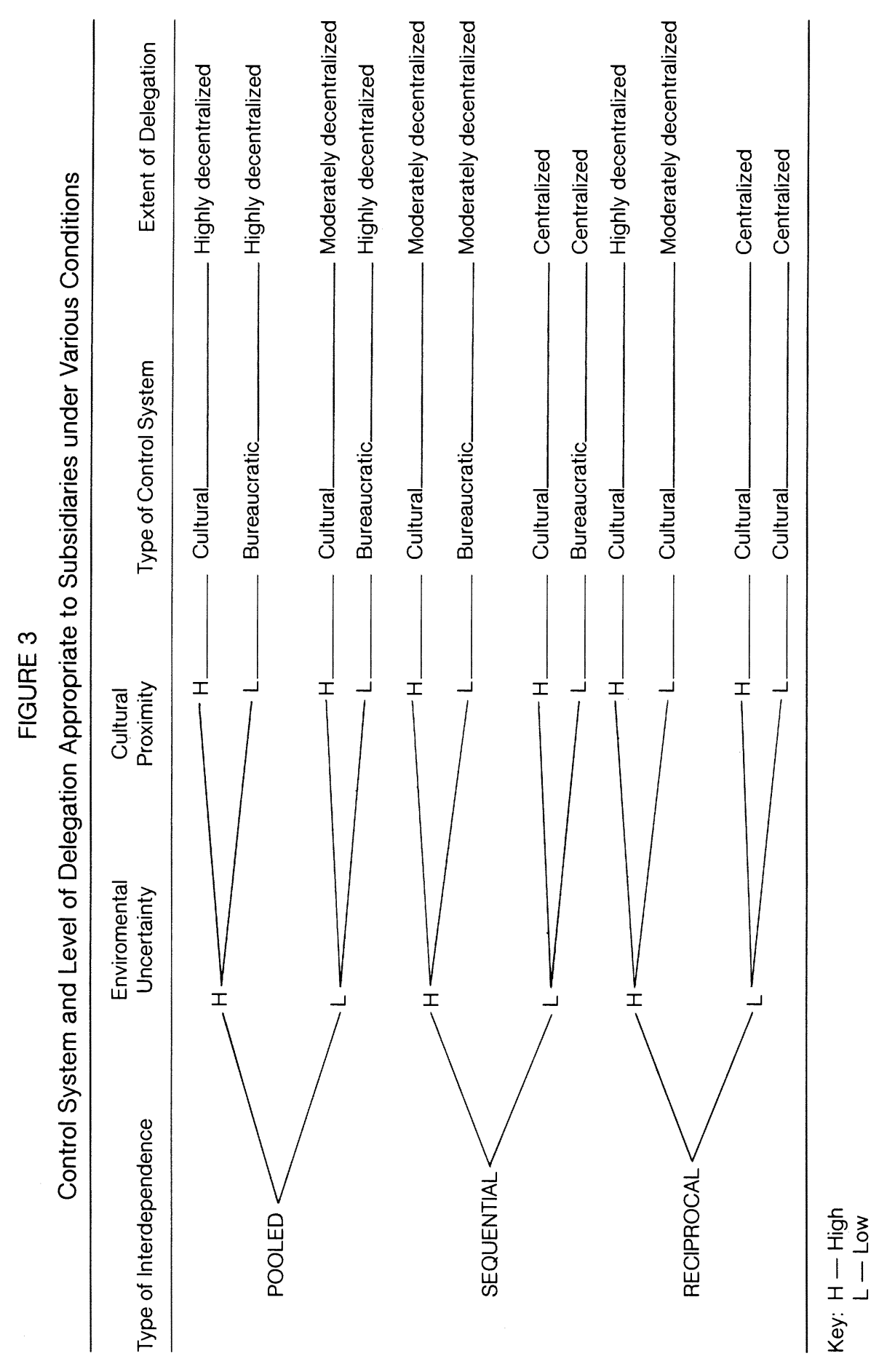


First, consider the potential problems associated with bureaucratic control systems. One example would be the situation where a low level of delegation is coupled with a bureaucratic control system in an inappropriate situation. In this situation one would probably find subsidiary managers "faking" reports and "working around" headquarters' mandated rules and regulations in order to wrest a measure of autonomy. Subsidiary managers who do not react in such a manner would probably feel frustrated and leave the firm. A related problem of a high level of bureaucratic control along with centralization is the creation of a "follow the rules and regulations" mind-set in subsidiary executives.

Even if the headquarters-subsidiary relationship is running smoothly, a low level of delegation can cause problems for the subsidiary management. This arises from the position of the subsidiaries (and their managers) in the overall organization. Many subsidiaries and their managers fall in the middle levels of organizational hierarchy, and, thus, are limited in terms of their status and power in the organization. Unfortunately, these very subsidiaries are fairly substantial organizations in their host environment, and their managers are often called upon to make decisions which are strategic in nature. In many instances they are unable to do so without referral to headquarters, and they come to be perceived as mere pawns under direct and total control by headquarters. This perception of a "headless" subsidiary [Mintzberg 1979] reinforces notions of domination by a "foreign" power in many a less-developed country.

A potential advantage to employing bureaucratic control systems in host environments probably stems from its "neutrality." Although formal results and goals must be achieved, the behaviors associated with their attainment can be consistent with local practices. These subsidiaries, in theory, will thus be more able to blend in with the local culture [Jaeger 1982].

A number of concerns are associated also with an organization's use of a cultural control system. An important one is that of costs and the limited ability of the system to handle turnover. As has been pointed out earlier, cultural control systems generally limit the organization size. If a multinational were strongly committed to a cultural control system it would probably have to sacrifice some economies of scale, thereby further increasing costs. Furthermore, if demand fluctuates widely, the firm would not be able to adjust its labor force accordingly. Hence, companies that operate in industries that are extremely price-competitive and cost-sensitive or are very cyclical may have a limited ability to utilize cultural control systems.

Another concern could arise from the fact that firms employing cultural control import into a host country a culture that may be distinctly different if cultural proximity is low. Most host governments generally keep an eye on movements of capital and technology but are rarely alert to cultural influences in specific cases: Whether the importation of this culture is positive or negative is difficult to assess generally. If the company culture is in serious conflict with local laws or customs, it might be difficult for the company to change its behavior in order to comply with them, especially if this culture is constantly reinforced by headquarters. Japanese firms have had such problems in imposing their organizational culture in their Asian subsidiaries [Kobayashi 1982].

Although cultural control systems may be of immense value to subsidiaries in reacting to local developments in a manner consistent with headquarters' intent (as a result of the socialization and indoctrination), they may have difficulty responding to a major environmental change, especially if it threatens the culture or calls for a radical change in thinking within the firm. Most change in a cultural control system must, of necessity, be incremental in nature. One cannot change peoples' beliefs overnight nor can one replace people quickly. Radical changes can occur only in extreme cases where the firm's survival is at stake and a "revolutionary" atmosphere can be created.

Overall, however, cultural control systems have many advantages. If, through a 
process of socialization and indoctrination, the managers do, in fact, develop a "moral commitment" to the organization, they can be accorded wide latitude, enabling them to respond to local conditions quickly and in a manner consistent with overall organizational goals and objectives. Also, if the cultural control system sanctions risk-taking and does not punish it, then managers will attempt innovative approaches to problems. This strengthens the quality of management within the system. Such risk-taking behavior is relatively more difficult to encourage in bureaucratic control systems since rule adherence is prized and too many exceptions cannot be tolerated without violating the sanctity of the rules.

A dilemma facing quite a few multinational corporations is how to keep good subsidiary managers motivated in subsidiaries that demand bureaucratic control systems along with fairly high levels of centralization. Such subsidiaries are ideally suited as initial assignment locations for junior executives. Junior executives can obtain a feel for international operations in a fairly controlled environment. After such exposure they could be transferred to more demanding situations that utilize cultural control and provide higher levels of delegation. In the interim they could be constantly socialized to the organizational culture.

The foregoing discussion suggests several interesting issues for investigation. For example, do high performance subsidiaries have levels of delegation appropriate to the demands generated by their interdependencies, their environmental uncertainty, and their cultural proximity? Does utilization of a cultural control system make it easier for a multinational subsidiary to adopt a low profile? Do host governments' demands to "localize" subsidiary management make it impossible to adopt cultural control systems? Is it easier to generate a geocentric orientation with a bureaucratic control system or a cultural control system?

A related area of fruitful investigation would be to determine the degree to which concerns of cultural proximity influence the foreign direct investment strategies adopted by multinational corporations; that is, are $\mathrm{MNC}$ executives driven more by how comfortable they feel managing a subsidiary in a country that is culturally closer to their own than by other considerations? Robinson [1978] suggests, indirectly, that the rigid preference of Japanese for cultural control in their large organizations coupled with their relative cultural distance from most foreign countries helps explain their extensive use of trading companies overseas as opposed to wholly-owned, host-country-staffed overseas subsidiaries.

There is a great potential payoff from further investigation of these issues. Results from such research could add considerably to knowledge of the functioning of multinational corporations.

In summary, this paper has focused on control and delegation issues confronting multinational corporation managers. Based on this, a conceptual framework has been advanced to assist multinational corporation managers in selecting the appropriate control system and level of delegation, essentially by stressing the notion of fit between these and the variables of interdependence, environmental uncertainty, and cultural proximity. Overall, it is most critical that multinational corporation headquarters' managers recognize the distinction between type of control and the extent of delegation, and that they refrain from treating subsidiaries similarly in terms of control systems and extent of delegation. This is no easy task, but it needs to be undertaken in order to ensure that subsidiaries are controlled in the optimum fashion.

Abegglen, J. C. The Japanese Factory: Aspects of its Social Organization. Free Press, 1958. 
Barnard, C. The Functions of the Executive. Harvard University Press, 1951.

Beyer, J. M., and Lodahl, T. M. "A Comparative Study of Patterns of Influence in United States and English Universities." Administrative Science Quarterly, March 1976, pp. 104-129.

Blau, P. M.; Falbe, C. M.; McKinley, W.; and Tracy, D. K. "Technology and Organization in Manufacturing." Administrative Science Quarterly, March 1976, pp. 20-40.

Blau, P. M., and Schoenherr, P. A. The Structure of Organizations. Basic Books, 1971.

Braybrooke, D., and Lindblom, C. E. A Strategy of Decision. Free Press, 1963.

Burns, T., and Stalker, G. M. The Management of Innovation, 2nd ed. Tavistock, 1966.

Child, J. Organization: A Guide to Problems and Practice. Harper \& Row, 1977.

"Strategies of Control and Organizational Behavior." Administrative Science Quarterly, March 1973, pp. 1-17.

"Organization Structure and Strategies of Control: A Replication of the Aston Study."

Administrative Science Quarterly, June 1972, pp. 163-177.

Child, J., and Keiser, A. "Organization and Managerial Role in British and West German Companies-An Examination of the Culture-Free Thesis." In Organizations Alike and Unlike, edited by C. J. Lamers and D. J. Hickson. Routledge and Kegan Paul, 1978.

Child, J., and Mansfield, R. "Technology, Size, and Organization Structure." Sociology, September 1972, pp. 369-393.

Clark, R. The Japanese Company. Yale University Press, 1979.

Crozier, M. The Bureaucratic Phenomenon, English translation. University of Chicago Press, 1964.

Deal, Terrence E., and Kennedy, Allan A. Corporate Cultures: The Rites and Rituals of Corporate Life. Addison-Wesley, 1982.

Donaldson, L. "Organizational Status and the Measurement of Centralization." Administrative Science Quarterly, September 1975, pp. 453-456.

Doz, Yves. "Strategic Management in Multinational Companies." Sloan Management Review, Winter 1980, pp. 27-46.

Duncan, R. B. "Characteristics of Organizational Environments and Perceived Environmental Uncertainty." Administrative Science Quarterly, September 1972, pp. 313-327.

Dyas, G. P., and Thanheiser, H. T. The Emerging European Enterprise: Strategy and Structure in French and German Industry. MacMillan of London, 1976.

Edström, A., and Galbraith, J. R. "Transfer of Managers as a Coordination and Control Strategy in Multinational Organizations." Administrative Science Quarterly, June 1977, pp. 248-263.

Emery, J. Organizational Planning and Control Systems. Macmillan, 1969.

Etzioni, A. "Compliance Structures." In A Sociological Reader on Complex Organizations, 3rd ed., edited by A. Etzioni and E. Lehman. Holt, Rinehart and Winston, 1980, pp. 87-100.

Fayerweather, J. International Business Strategy and Administration. Ballinger, 1978.

Filley, A. C.; House, R. J.; and Kerr, S. Managerial Process and Organizational Behavior. Scott, Foresman, 1976.

Galbraith, J. R. Designing Complex Organizations. Addison-Wesley, 1973.

Greenwood, R., and Hinings, C. R. "A Research Note: Centralization Revisited." Administrative Science Quarterly, March 1976, pp. 151-155.

Hage, J., and Aiken, M. "Relationship of Centralization to Other Structural Properties." Administrative Science Quarterly, June 1967, pp. 72-92.

Hall, R. T. "Professionalization and Bureaucratization." American Sociological Review, February 1968, pp. 92-104.

Organizations: Structure and Process. Prentice-Hall, 1972.

Hatvany, Nina, and Pucik, Vladimir. "An Integrated Management System: Lessons from the Japanese Experience." Academy of Management Review, July 1981, pp. 469-480.

Hulburt, James M., and Brandt, William K. "Patterns of Communications in the Multinational Corporation: An Empirical Study." Journal of International Business Studies, Spring 1976, pp. 57-64.

Inkson, J.H.K.; Pugh, D. S.; and Hickson, D. J. "Organization Context and Structure: An Abbreviated Replication." Administrative Science Quarterly, September 1970, pp. 318-329.

Jaeger, Alfred M. "Contrasting Control Modes in the Multinational Corporation: Theory, Practice and Implications." International Studies of Management and Organization 12, no. 1 (1982), pp. 59-82.

"The Transfer of Organizational Culture Overseas: An Approach to Control in the Multinational Corporation." Journal of International Business Studies, Fall 1983, pp. 115-129. Jay, A. Management and Machiavelli. Penguin, 1970.

Johnson, R. T., and Ouchi, W. G. "Made in America (Under Japanese Management)." Harvard Business Review, September-October 1974, pp. 61-91. 
Kaufman, H. The Forest Ranger: A Study in Administrative Behavior. Johns Hopkins Press, 1960. Keesing, R. "Theories of Culture." Annual Review of Anthropology 1974, pp. 73-97.

Khandwalla, P. N. The Design of Organizations. Harcourt Brace Jovanovich, 1977.

Kimberly, J. R. "Organizational Size and the Structuralist Perspective: A Review, Critique, and Proposal." Administrative Science Quarterly, December 1976, pp. 571-597.

Kobayashi, Noritake. "The Present and Future of Japanese Multinational Enterprises." International Studies of Management and Organization 12, no. 1 (1982), pp. $38-58$.

Kochen, M., and Deutsch, K. W. "Decentralization by Function and Location." Management Science, April 1973, pp. 841-855.

Kuin, P. "The Magic of Multinational Management." Harvard Business Review, NovemberDecember 1972, pp. 89-97.

Lawrence, P. R. The Changing Organizational Behavior Patterns. Riverside Press, 1958 , and Lorsch, J. W. Organization and Environment. Irwin, 1967.

Linton, R. The Study of Man. D. Appleton Century Company, 1936.

Litterer, J. A. The Analysis of Organizations. Wiley, 1965; also 2nd ed., 1973.

Lorsch, J.W. "Introduction to the Structural Design of Organizations." In Organizational Structure and Design, edited by G. W. Dalton, P. R. Lawrence, and J. W. Lorsch. Irwin Dorsey, 1970.

Manns, C. Review of "Formalization and Centralization: The Case of Polish Industry" by Lena Kolarska. In Seminars on Organizations, edited by A. M. Jaeger. Stanford University, Palo Alto, California, Winter and Spring 1976, pp. 64-66.

Mansfield, R. "Bureaucracy and Centralization: An Examination of Organizational Structure." Administrative Science Quarterly, December 1973, pp. 477-488.

Mintzberg, H. The Structuring of Organizations. Prentice-Hall, 1979.

Ouchi, W. G. Theory Z. Addison-Wesley, 1981.

"The Relationship Between Organizational Structure and Organizational Control." Administrative Science Quarterly, March 1977, pp. 95-112.

Ouchi, W. G., and Jaeger, A. M. "Type Z Organization: Stability in the Midst of Mobility." Academy of Management Review, April 1978, pp. 305-314.

Ouchi, W. G., and McGuire, M. A. "Organizational Control: Two Functions." Administrative Science Quarterly, December 1975, pp. 559-569.

Pascale, R. T., and Athos, A. G. The Art of Japanese Management. Simon \& Schuster, 1981.

Perrow, C. "A Framework for the Comparative Analysis of Organizations." American Sociological Review, April 1967, pp. 194-208.

. Organizational Analysis: A Sociological Review. Wadsworth, 1970.

Peters, T. J., and Waterman, R. H. Jr. In Search of Excellence. Harper \& Row, 1983.

Pugh, D. S.; Hickson, D. J.; Hinings, C. R.; Macdonald, K. M.; Turner, C.; and Lupton, T. "A Conceptual Scheme for Organizational Analysis." Administrative Science Quarterly, December 1963-64, pp. 289-315.

Pugh, D. S.; Hickson, D. J.; Hinings, C. R.; and Turner, C. "Dimensions of Organization Structure." Administrative Science Quarterly, June 1968, pp. 65-105.

Reimann, B. C. "On the Dimensions of Bureaucratic Structure: An Empirical Reappraisal." Administrative Science Quarterly, December 1973, pp. 462-476.

Robbins, S. P. Organization Theory: The Structure and Design of Organizations. Prentice-Hall, 1983.

Robinson, Richard D. International Business Management: A Guide to Decision Making. Dryden Press, 1978.

Rohlen, T. P. For Harmony and Strength: Japanese White Collar Organization in Anthropological Perspective. University of California Press, 1974.

Scharpf, F. W. "Does Organization Matter? Task Structure and Interaction in the Ministerial Bureaucracy." In Organization Design: Theoretical Perspectives and Empirical Findings, edited by E. H. Burack and A. R. Negandhi. Kent State University Press, 1977, pp. 149-167.

Schein, E. H. Organizational Psychology. Prentice Hall, 1980.

Schwartz, H., and Davis, S. M. "Matching Corporate Culture and Business Strategy." Organizational Dynamics, Summer 1981, pp. 30-48.

Simon, H. A. Administrative Behavior, 2nd ed. Macmillan, 1957.

Smircich, Linda "Concepts of Culture and Organizational Analysis." Administrative Science Quarterly, September 1983, pp. 339-358.

Stinchcombe, A. L. "Bureaucratic and Craft Administration of Production: A Comparative Study." Administrative Science Quarterly, September 1959, pp. 168-187.

Stopford, J. M., and Wells, L. T. Jr. Managing the Multinational Enterprise: Organization of the Firm and Ownership of the Subsidiaries. Basic Books, 1972. 
Tannenbaum, A. Control in Organizations. McGraw Hill, 1968.

Thompson, J. D. Organizations in Action. McGraw Hill, 1967.

Vernon, R. "International Investment and International Trade in the Product Cycle." Quarterly Journal of Economics, May 1966, pp. 190-207.

Weick, K. E. "Educational Organizations as Loosely Coupled Systems." Administrative Science Quarterly, March 1976, pp. 1-19.

Wilkins, Alan L. "Organizational Stories as an Expression of Management Philosophy." Unpublished doctoral dissertation, Graduate School of Business, Stanford University, 1980.

and Ouchi, William G. "Efficient Cultures: The Relationship Between Culture and Organizational Performance." Administrative Science Quarterly, September 1983, pp. 468-481. Woodward, J. Industrial Organization: Theory and Practice. Oxford University Press, 1965. 